\title{
Dinamika Kedudukan Interface di Pesisir Kabupaten Kebumen, Jawa Tengah
}

\section{Ig.L.Setyawan Purnama}

Departemen Geografi Lingkungan, Fakultas Geografi, Universitas Gadjah Mada, Yogyakarta, Indonesia

Email koresponden: Setyapurna@geo.ugm.ac.id

Diterima : Juni 2017 ; Direvisi : Juli 2017; Dipubikasikan: September 2017

@2017 Fakultas Geografi UGM dan Ikatan Geograf Indonesia

\begin{abstract}
Abstrak Interface adalah mintakat pertemuan antara air laut yang bersifat asin dan airtanah di daratan yang bersifat tawar. Interface tidak ditemukan dalam wilayah yang tegas, namun merupakan wilayah percampuran antara air tawar dan air asin, sehingga keberadaan Interface tidak bersifat statis melainkan dinamis. Penelitian ini bertujuan untuk (1) mengetahui dan menganalisis kedudukan Interface di Pesisir Kabupaten Kebumen dan (2) menganalisis dinamika kedudukan Interface selama kurun waktu 21 tahun yaitu tahun 1993 dan 2014. Kedudukan Interface diketahui berdasarkan pendugaan geolistrik rangkaian Schlumberger. Pendugaan dilakukan pada lokasi dan jalur yang sesuai dengan penelitian yang dilakukan oleh Simoen dkk. (1993), yaitu pada (1) jalur Salak-Petanahan-Munggu-Gadung-Pantai Petanahan, (2) jalur Tambakrejo-Jeblok-PrajuritanAdikarto-Pantai Kebumen dan (3) jalur Sinungrejo-Sidoluhur-Bener-Kaibon-Ambal dan Pantai Kutowinangun. Perbandingan hasil pendugaan Interface di kedua waktu tersebut akan diketahui perbedaan dan persamaan kedalaman Interface pada masingmasing titik pengukuran dalam selang waktu 21 tahun dan selanjutnya dapat dianalisis faktor-faktor yang mempengaruhinya. Hasil penelitian menemukan adanya lapisan airtanah tawar mulai kedalaman 2 hingga 10 meter dari permukaan tanah. Berbeda dengan di tahun 1993, hasil pendugaan di tahun 2014 tidak mendeteksi adanya Interface di semua jalur pengukuran. Tidak terdeteksinya Interface disebabkan kedudukan Interface semakin dalam akibat desakan airtanah tawar yang semakin kuat.
\end{abstract}

Kata kunci : Interface, Geolistrik, Pesisir, Kebumen

Abstract An Interface is a zone where seawater (salt) and inland groundwater (fresh) meet. It has no distinct boundaries because it is formed by a mixture of fresh and saltwater. Therefore, the presence of Interface is not static or somewhat dynamic. This research aimed to (1) identify and analyze the position of salt-freshwater Interface in the Coast of Kebuman Regency and (2) analyze the dynamics of the said Interface at a timespan of 21 years, i.e., in 1993 and 2014. The position was estimated using geoelectrical sounding with Schlumberger arrangement. The estimation was conducted in the locations and along the lines that were determined based on the research performed by Simoen et al. (1993). The lines traversed the following areas (1) Salak-Petanahan-MungguGadung-Petanahan Coast, (2) Tambakrejo-Jeblok-Prajuritan-Adikarto-Kebumen Coast, and (3) the Sinungrejo-Sidoluhur-BenerKaibon-Ambal-Kutowinangun Coast. The comparison of the estimated Interfaces in two observation years yielded depth differences and similarities at every measurement point. This information, then, provided the underlying factors of the dynamic Interface. The research found a freshwater layer at a depth of 2 to $10 \mathrm{~m}$ from the soil surface. Unlike the estimation results in 1993, the ones in 2014 did not detect any presence of Interface in all of the measurement lines. The Interface was undetected because it lowered as the pressure of fresh groundwater became stronger.

Key words : Interface; Geoelectric; Coast; Kebumen

\section{PENDAHULUAN}

Sebagai negara kepulauan, $70 \%$ wilayah Indonesia berupa lautan. Sisanya berupa daratan dengan garis pantai sepanjang kurang lebih $81.000 \mathrm{~km}$. Beberapa kota besar dengan penduduk padat juga terdapat di sepanjang pesisir ini, sepertimisalnya Jakarta, Semarang, Surabaya, Banda Aceh, Padang, Makasar, Denpasar dan Jayapura (Marfai and King, 2008; Marfai dkk., 2013; Purnama dkk., 2015). Akibat berkembangnya kotakota tersebut, kebutuhan air minum yang terutama bersumber dari airtanah semakin besar (Purnama dan Sulaswono, 2006; Purnama dkk., 2013a), sementara imbuhan air relatif tetap atau bahkan justru berkurang karena berkurangnya peresapan air ke dalam tanah (Purnama, 2002).
Tingginya eksploitasi airtanah ini, apabila tidak menyebabkan penurunan muka tanah (land subsidence), dapat menyebabkan intrusi air laut (Purnama dkk., 2013b). Dampak kedua inilah ternyata yang lebih sering terjadi, sehingga telah menjadi permasalahan penting di kota-kota yang terletak di daerah pesisir.

Salah satu metode identifikasi terjadinya intrusi air laut di daerah pesisir adalah dengan memperhatikan mintakat pertemuan antara air laut yang bersifat asin dan airtanah di daratan yang bersifat tawar yang disebut Interface. Menurut Basack et al. (2010), wilayah Interface merupakan mintakat transisi air dan terjadinya difusi antara air tawar dan air asin. Jenis air yang terdapat di bawah Interface adalah air asin, sedangkan di atas Interface berupa airtanah tawar. Mintakat Interface ini 
bukanlah merupakan wilayah statis. Apabila desakan air tanah tawar dari daratan terhadap air laut kuat, Interface akan makin ke arah laut atau sangat dalam, sebaliknya apabila desakan airtanah tawar melemah, air laut akan mendesak ke darat dan Interface akan makin dangkal. Melemahnya desakan airtanah tawar ini antara lain dapat disebabkan oleh berkurangnya jumlah air karena pengambilan yang melebihi hasil amannya. Selain terjadi dinamika pergerakan antar zat cair, pada mintakat ini juga dapat terjadi beberapa proses kimia, seperti misalnya pertukaran ion antara $\mathrm{Ca} 2+$ dengan $\mathrm{Mg} 2+$ atau antara $\mathrm{Ca} 2+$ dengan $\mathrm{Na} 2+$ (Goldenberg et al., 1983).

Kedalaman Interface dapat diperkirakan dengan persamaan Ghyben-Herzberg. Menurut persamaan ini, kedalaman Interface dapat diperkirakan berdasarkan (1) elevasi muka airtanah di atas muka air laut, (2) densitas air asin dan (3) densitas air tawar. Menurut Todd dan Mays (2005) dan Rushton (2003), karena densitas air asin sebesar 1,025 g/cm3 dan densitas air tawar sebesar $1,000 \mathrm{~g} / \mathrm{cm} 3$, maka kedalaman Interface di suatu akuifer pesisir dapat diperkirakan sebesar 40 kali elevasi muka airtanah di atas muka air laut di tempat tersebut.

Selain kedalamannya, aliran airtanah di akuifer pantai juga dapat ditentukan yaitu menggunakan kombinasi antara persamaan Dupuit dan prinsip Ghyben-Herzberg (Fetter, 2001). Persamaan ini mengharuskan diperhatikannya imbuhan air ke dalam akuifer, konduktivitas hidrolik, densitas air tawar, densitas air laut, jarak dari garis pantai dan ketinggian muka freatik dari muka air laut.

Kedalaman Interface juga dapat ditentukan dengan pengukuran geolistrik (Saha and Choudhury, 2005). Teknik ini dapat digunakan untuk menentukan stratigrafi batuan dan nilai tahanan jenis airtanah yang terdapat di dalamnya. Air tawar mempunyai nilai tahanan jenis yang berbeda dibandingkan dengan air asin. Akuifer airtanah pada batuan sedimen seperti pada pasir yang jenuh air asin nilai tahanan jenisnya $<1 \Omega \mathrm{m}$.

Fenomena yang cukup menarik adalah bahwa ternyata keberadaan Interface bukan hanya terdeteksi pada wilayah perkotaan yang penduduknya padat, namun juga pada daerah perdesaan yang penduduknya jarang seperti misalnya di wilayah pesisir Kabupaten Kebumen. Hasil pendugaan geolistrik yang dilakukan Simoen dkk. (1993) di wilayah pesisir Kebumen, menunjukkan adanya Interface di tiga jalur pengukuran yaitu (1) jalur Salak - Petanahan - Munggu - Gadung - Pantai Petanahan, (2) jalur Tambakrejo - Jeblok Prajuritan - Adikarto - Pantai Kebumen dan (3) jalur Sinungrejo - Sidoluhur - Bener - Kaibon - Ambal dan Pantai Kutowinangun. Menurut Simoen dkk. (1993), terdeteksinya Interface di wilayah pesisir Kebumen ini disebabkan karena sumber airtanah di daerah ini hanya berasal dari air hujan yang jatuh di daerah beting pantai, sehingga air tawar tidak cukup kuat untuk mendesak air laut. Selain itu, daerah back swamp (rawa belakang) yang terdapat di wilayah ini juga sering kemasukan air laut pada saat pasang.

Pengetahuan lebih detil terkait dengan terdeteksinya Interface saat ini di Pesisir Kebumen dapat dilakukan dengan pendugaan geolistrik, sehingga dapat diketahui dinamika kedudukan Interface tersebut secara temporal dan diketahui penyebabnya secara lebih detil. Berdasarkan hal ini, maka tujuan dari penelitian ini ada dua yaitu (1) mengetahui dan menganalisis kedudukan Interface di daerah penelitian dan (2) menganalisis dinamika kedudukan Interface selama 21 tahun yaitu dari tahun 1993 dan 2014

\section{METODE PENELITIAN}

\section{Bahan dan Alat}

Bahan yang diperlukan dalam penelitian ini meliputi (1) Peta Rupa Bumi Indonesia, (2) Peta Hidrogeologi dan (3) laporan hasil penelitian dan data instansional yang terkait dengan karakteristik wilayah pesisir Kabupaten Kebumen. Adapun peralatan yang diperlukan meliputi satu set peralatan geolistrik dan GPS (Global Positioning System).

Data yang diperlukan dalam penelitian ini meliputi:

a). Data karakteristik geomorfologi, meliputi prosesproses geomorfologi dan batuan/materi penyusun dan strukturnya;

b). Data geologi dan jenis tanah;

c). Data karakteristik hidrologi, yaitu kedudukan muka airtanah; dan

d). Datahasil-hasilpenelitiandanpelaporanterdahulu yang terkait dengan kondisi hidrogeologi daerah penelitian.

Kedudukan Interface diketahui berdasarkan pada pendugaan geolistrik. Karena tujuan penelitian ini untuk mengetahui kedalaman dan perlapisan batuan ke arah dalam atau vertikal, maka rangkaian yang digunakan adalah rangkaian Schlumberger. Sesuai dengan penelitian yang dilakukan oleh Simoen dkk. (1993), penelitian dilakukan pada 3 jalur pendugaan geolistrik yaitu (1) jalur Salak - Petanahan - Munggu - Gadung - Pantai Petanahan, (2) jalur Tambakrejo Jeblok - Prajuritan - Adikarto - Pantai Kebumen dan (3) jalur Sinungrejo - Sidoluhur - Bener - Kaibon Ambal dan Pantai Kutowinangun. Secara lebih jelas, jalur yang digunakan dalam penelitian ini ditunjukkan oleh Gambar 1. 


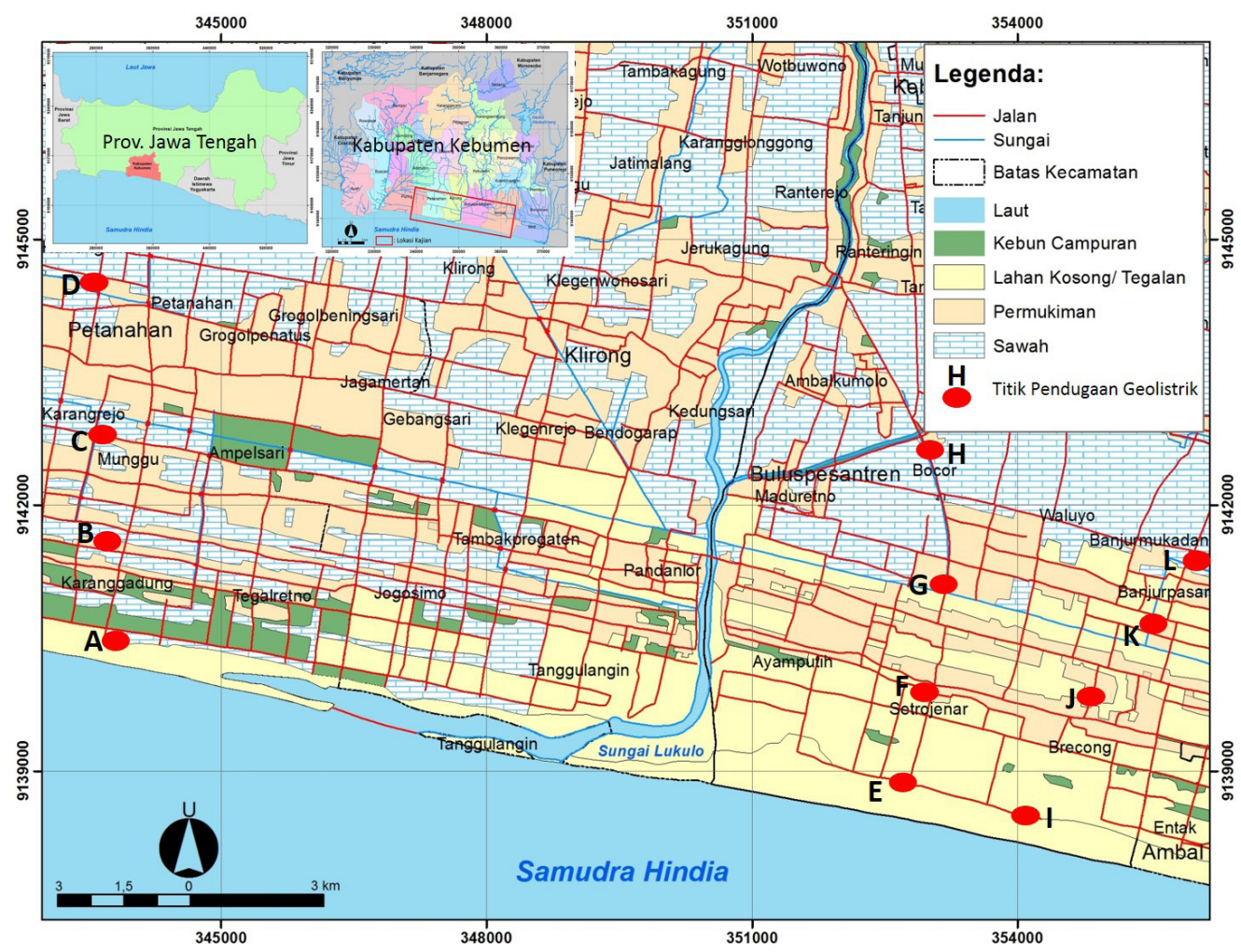

Gambar 1. Jalur pendugaan geolistrik

Cara kerja rangkaian geolistrik Schlumberger adalah dengan mengalirkan arus listrik searah ke dalam tanah melalui dua buah patok besi. Besarnya kuat arus yang dialirkan ke dalam tanah diukur dengan amperemeter. Akibat adanya aliran listrik searah ini, akan terjadi perubahan potensial tanah. Melalui dua buah patok tembaga yang ditancapkan di antara kedua patok besi, dapat diketahui perubahan tersebut dan diukur besarnya menggunakan voltmeter. Dalam penelitian ini, rangkaian elektroda arus (patok besi) serta elektroda potensial (patok tembaga) dimulai pada jarak 1,5 meter dan diakhiri pada jarak 250 meter. Prinsipnya, semakin jauh jarak rentangan patok besi, akan semakin dalam lapisan batuan yang terukur, yang linear dengan jarak rentangannya.

\section{Metode Analisis Data}

Seperti telah diuraikan sebelumnya, pada pendugaan lapangan, nilai yang terukur adalah nilai kuat arus dan nilai potensial. Penentuan nilai tahanan jenis dihitung dengan rumus pada persamaan 1 (Zohdy et al., 1980).

\section{$\Delta \mathrm{V}$}

$$
\mathrm{R}=\mathrm{K}
$$

dengan $\mathrm{R}$ adalah tahanan jenis, $\mathrm{K}$ adalah konstanta (tergantung pada jarak elektroda), $\Delta \mathrm{V}$ adalah perubahan potensial dan I adalah kuat arus. Nilai K ditentukan berdasarkan persamaan dasar arus listrik searah yang disebut sebagai faktor geometri dari rangkaian elektroda (Persamaan 2 dalam Zohdy et al., 1980).

2

\section{(2) $1 / \mathrm{C} 1 \mathrm{P} 1-1 / \mathrm{C} 2 \mathrm{P} 1-1 / \mathrm{C} 1 \mathrm{P} 2+1 / \mathrm{C} 2 \mathrm{P} 2$}

Data hasil pendugaan geolistrik di lapangan merupakan data tahanan jenis semu. Penentuan nilai tahanan jenis aktualnya harus dilakukan penafsiran data, yang dalam penelitian ini digunakan software IP2WIN. Sebagai input adalah data jarak elektrode arus $1 / 2 \mathrm{~L}$ (dalam meter) dan nilai tahanan jenis (dalam $\Omega \mathrm{m}$ ).

\section{Analisis Dinamika Interface}

Kedudukan dan dinamika kedudukan Interface di daerah penelitian dianalisis dengan membandingkan hasil pendugaan di tahun 2014 dengan hasil pendugaan geolistrik di lokasi yang sama, yang dilakukan oleh Simoen dkk. pada tahun 1993. Perbandingan tersebut dapat digunakan untuk mengetahui perbedaan dan persamaan kedalaman Interface pada masing-masing titik pendugaan dalam selang waktu 21 tahun. 


\section{HASIL DAN PEMBAHASAN}

\section{Letak dan Batas}

Secara administratif, lokasi penelitian terletak di wilayah Kabupaten Kebumen, Provinsi Jawa Tengah, khususnya meliputi Kecamatan Ambal, Bulupesantren, Klirong dan Petanahan. Ditinjau dari batas wilayahnya, di bagian barat dibatasi Kabupaten Gombong, di bagian timur oleh Kabupaten Purworejo, di bagian selatan oleh Samudra Hindia dan di bagian utara oleh Kabupaten Wonosobo dan Banjarnegara.

\section{Keadaan Iklim}

Keadaan iklim di Pesisir Kabupaten Kebumen tidak dapat dilepaskan dari kondisi iklim Pulau Jawa secara keseluruhan, yang dipengaruhi oleh angin muson, yaitu angin global yang bertiup akibat pengaruh letak matahari, sehingga akan selalu berganti arah setiap setengah tahun. Selama bulan Oktober hingga April ketika matahari terletak di belahan Bumi selatan, daratan Australia merupakan daerah pusat tekanan rendah, sehingga angin bertiup dari daratan Asia yang merupakan pusat tekanan tinggi. Ketika melalui khatulistiwa angin ini dibelokkan arahnya dari timur lautan (North-Easterly) menjadi barat lautan (NorthWesterly). Saat melewati Pulau Jawa, angin muson yang basah ini menjadi angin barat, sehingga sering disebut angin muson barat yang basah (Wet-West Monsoon). Periode tersebut Pulau Jawa umumnya dan Pesisir Kebumen khususnya mengalami musim hujan. Sebaliknya, pada bulan Mei hingga Oktober, daratan Asia menjadi pusat tekanan rendah dan Australia menjadi pusat tekanan tinggi. Angin muson bertiup dari Australia dan tidak membawa uap air (East-dry monsoon), sehingga sebagian Pulau Jawa mengalami musim kemarau.

Berdasarkan pembagian tipe iklim dari Koppen, tipe iklim di Pesisir Kebumen adalah Am. Pada tipe Am, jumlah curah hujan yang jatuh di bulan basah dapat mengimbangi musim kering yang pendek. Jadi meskipun di daerah beriklim Am ini memiliki satu atau dua bulan kering, tetapi curah hujan di bulan lainnya cukup tinggi, sehingga vegetasi yang ada tidak begitu terpengaruh oleh periode kering pendek tersebut.

Ditinjau dari jumlah curah hujannya, curah hujan di Pesisir Kebumen tergolong tinggi yaitu antara 2.500 $\mathrm{mm} /$ tahun sampai dengan $5.000 \mathrm{~mm} /$ tahun. Curah hujan bulanan tertinggi terjadi pada Bulan November yakni sebesar $426 \mathrm{~mm}$, sedangkan curah hujan bulanan terendah terjadi pada Bulan Agustus yakni sebesar 18 $\mathrm{mm}$. Curah hujan tahunan rata-rata tercatat sebesar $2.647 \mathrm{~mm}$.

\section{Kondisi Geologi dan Geohidrologi Lokasi Kajian}

Pesisir Selatan Kabupaten Kebumen tersusun dari material aluvium. Material aluvium pada bagian Barat dibatasi oleh kawasan karst berbatuan gamping di wilayah Karangbolong yang merupakan bagian dari pegunungan selatan. Alas dari kawasan karst ini terdiri atas breksi andesit tua yang tertutup oleh lapisan batu gamping secara tidak selaras. Batu gamping dari Formasi Sentolo dan breksi andesit tua bersisipan lapisan tufa dapat ditemukan di bagian utara.

Ditinjau dari kondisi geohidrologinya, Pesisir Kebumen termasuk dalam wilayah Cekungan Airtanah (CAT) Kebumen - Purworejo. Cekungan Airtanah ini pada bagian timur dibatasi oleh CAT Wates, di bagian barat oleh CAT Banyumudal, di bagian selatan oleh Samudra Hindia dan di sebelah utara oleh wilayah non-akuifer. Menurut Setiadi (2003), CAT KebumenPurworejo hanya memiliki satu lapisan akuifer yang berupa akuifer bebas. Akuifer bebas di CAT KebumenPurworejo ini mempunyai debit 130 juta m3/tahun.

\section{HASIL PENDUGAAN GEOLISTRIK}

\section{Jalur Salak-Petanahan-Munggu-Gadung-Pantai Petanahan}

Jalur pendugaan geolistrik ini terletak di antara Sungai Cingcingguling dan Sungai Luk Ulo. Secara geomorfologis, wilayah ini merupakan jalur beting gisik ganda. Material penyusunnya berupa pasir yang sudah berkembang menjadi tanah, sehingga telah dimanfaatkan oleh penduduk sebagai daerah permukiman. Hasil pendugaan geolistrik pada tahun 1993 menunjukkan adanya Interface hingga jarak 2,5 $\mathrm{km}$ dari pantai dengan kedalaman yang bervariasi. Selain itu, pada jarak 200 meter dari garis pantai terdeteksi Interface pada kedalaman 45 meter dari permukaan tanah dan pada jarak $1,5 \mathrm{~km}$ dari garis pantai terdeteksi Interface pada kedalaman 50 meter dari permukaan tanah, sedangkan pada jarak 2,5 km dari garis pantai terdeteksi Interface pada kedalaman 55 meter dari permukaan tanah. Hasil pendugaan pada jarak 4,2 km dari garis pantai, tidak mendeteksi adanya Interface (Gambar 2).

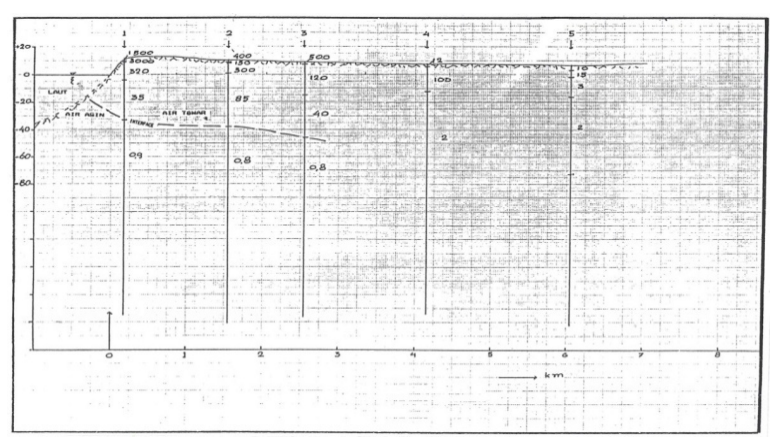

Gambar 2. Jalur Salak-Petanahan-MungguGadung-Pantai Petanahan tahun 1993

(Simoen dkk., 1993)

Hasil pendugaan geolistri pada tahun 2014, jalur ini meliputi empat titik pendugaan, yaitu titik A 
dengan jarak 0,3 km dari garis pantai terletak di Pantai Petanahan, titik B dengan jarak 1,3 km dari garis pantai terletak di Gadung, titik C dengan jarak 2,7 km dari garis pantai terletak di Munggu dan titik D dengan jarak dari pantai 4,2 km terletak di Petanahan. Hasil interpretasi data lapangan menunjukkan terdapatnya lapisan batuan dengan nilai tahanan jenis 10 hingga 30 $\Omega$ m mulai kedalaman 3 hingga 7 meter dari permukaan tanah. Lapisan ini diperkirakan merupakan lapisan pasir yang jenuh airtanah tawar (Gambar 3). Hasil pendugaan geolistrik pada jalur ini tidak mendeteksi adanya Interface karena tidak adanya nilai tahanan jenis kurang dari $1 \Omega \mathrm{m}$.

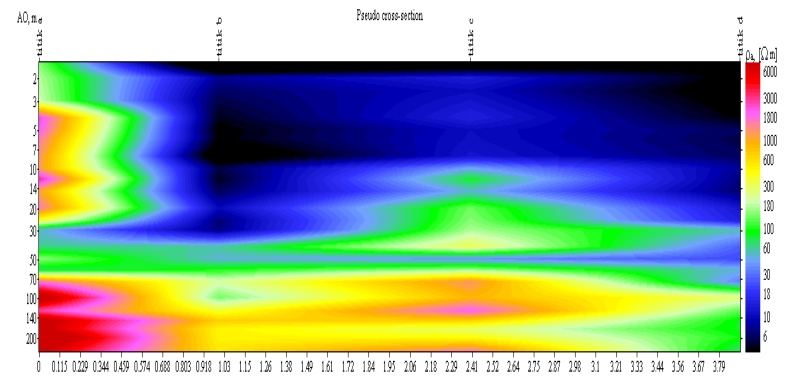

Gambar 3. Jalur Salak-Petanahan-MungguGadung-Pantai Petanahan tahun 2014

\section{Jalur Tambakrejo-Jeblok-Prajuritan-Adikarto- Pantai Kebumen}

Jalur pendugaan geolistrik ini terletak di sebelah timur Sungai Luk Ulo. Hasil pendugaan pada tahun 1993 mendeteksi terdapatnya Interface hingga jarak $4,5 \mathrm{~km}$ dari garis pantai. Hasil pendugaan geolistrik juga menunjukkan bahwa pada jarak 200 meter dari garis pantai terdeteksi Interface pada kedalaman 70 meter dari permukaan tanah. Selain itu, pada jarak 1,4 dan 2,3 km dari garis pantai terdeteksi Interface pada kedalaman 65 meter dari permukaan tanah, sedangkan pada jarak 4,5 km dari garis pantai terdeteksi Interface pada kedalaman 100 meter dari permukaan tanah. Interface sudah tidak terdeteksi lagi pada jarak $6,1 \mathrm{~km}$ (Gambar 4).

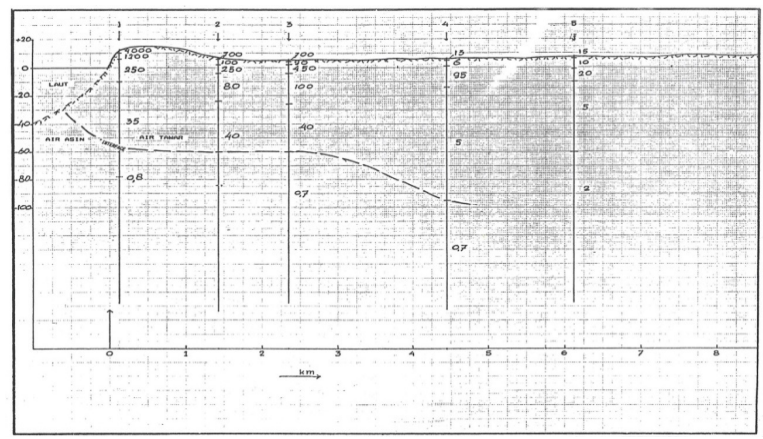

Gambar 4. Jalur Tambakrejo-Jeblok-PrajuritanAdikarto-Pantai Kebumen tahun 1993 (Simoen dkk., 1993)
Pendugaan geolistrik tahun 2014 juga dilakukan di empat titik pengukuran yaitu titik E yang terletak di Pantai Kebumen dengan jarak 0,2 km dari pantai, titik F yang terletak di Adikarto dengan jarak 1,2 km dari pantai, titik G yang terletak di Prajuritan dengan jarak 2,5 $\mathrm{km}$ dari pantai dan titik $\mathrm{H}$ yang terletak di Jeblog dengan jarak 4,3 km dari pantai. Hasil interpretasi data lapangan menunjukkan terdapatnya lapisan batuan dengan nilai tahanan jenis 10 hingga $20 \Omega \mathrm{m}$ mulai kedalaman 2 hingga 4 meter dari permukaan tanah (Gambar 5). Lapisan ini diperkirakan merupakan lapisan pasir yang jenuh airtanah tawar. Jalur ini juga menunjukkan bahwa Interface tidak terdeteksi karena tidak ada nilai tahanan jenis kurang dari $1 \Omega \mathrm{m}$.

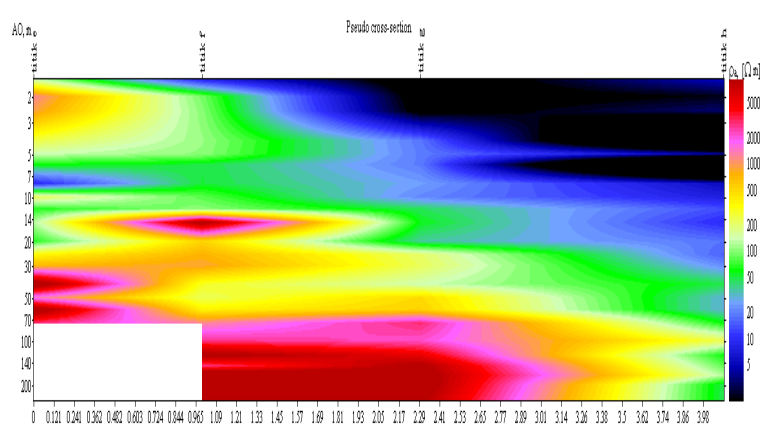

Gambar 5. Jalur Tambakrejo-Jeblok-PrajuritanAdikarto-Pantai Kebumen tahun 2014

\section{Jalur Sinungrejo-Sidoluhur-Bener-Kaibon-Ambal dan Pantai Kutowinangun}

Jalur pendugaan geolistrik ini terletak di sebelah barat Sungai Wawar. Hasil pendugaan pada tahun 1993 menunjukkan telah terdeteksinya keberadaan Interface hingga jarak $2,5 \mathrm{~km}$ dari garis pantai. Interface pada jarak 200 meter dari garis pantai terdeteksi pada kedalaman 50 meter dari permukaan tanah. Interface pada jarak $1,4 \mathrm{~km}$ dari garis pantai terdeteksi pada kedalaman 62 meter dari permukaan tanah, sedangkan pada jarak 2,5 km dari garis pantai terdeteksi Interface pada kedalaman 72 meter dari permukaan tanah. Selain itu, pada jarak $4,8 \mathrm{~km}$ dari garis pantai sudah tidak terdeteksi lagi adanya Interface (Gambar 6).

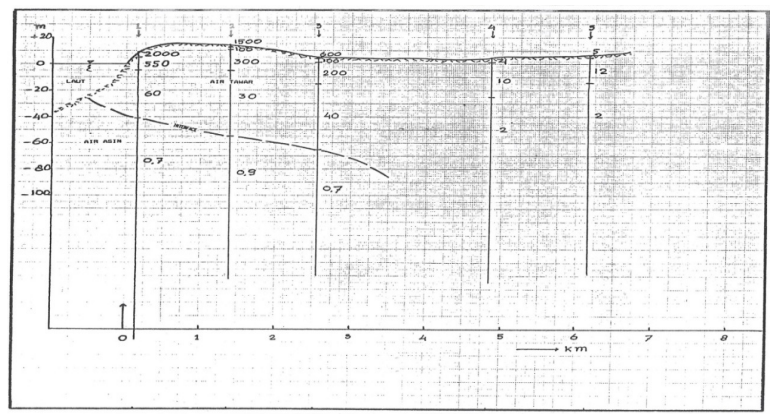

Gambar 6. Jalur Sinungrejo-Sidoluhur-BenerKaibon-Ambal dan Pantai Kutowinangun tahun 1993 (Simoen dkk., 1993) 
Seperti halnya pada jalur sebelumnya, pada tahun 2014 penampang ini juga terdiri atas empat titik pengukuran, yaitu titik I yang berjarak $0,2 \mathrm{~km}$ dari garis pantai, titik J yang berjarak $1,7 \mathrm{~km}$ dari garis pantai, titik $\mathrm{K}$ yang berjarak 2,5 $\mathrm{km}$ dari garis pantai serta titik $\mathrm{L}$ yang berjarak $3 \mathrm{~km}$ dari garis pantai. Hasil interpretasi data lapangan menunjukkan terdapatnya lapisan batuan dengan nilai tahanan jenis $20 \Omega \mathrm{m}$ hingga $50 \Omega \mathrm{m}$ mulai kedalaman 3,5 hingga 10 meter dari permukaan tanah (Gambar 7). Lapisan ini diperkirakan merupakan lapisan pasir yang jenuh airtanah tawar. Interface pada jalur ini juga tidak terdeteksi karena tidak ada nilai tahanan jenis kurang dari $1 \Omega \mathrm{m}$.

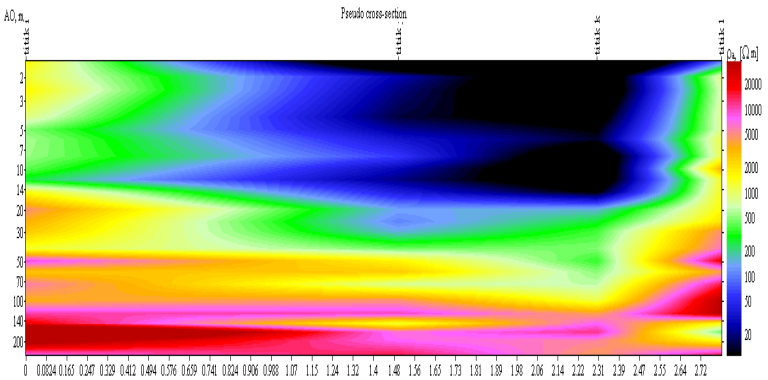

Gambar 7. Jalur Sinungrejo-Sidoluhur-BenerKaibon-Ambal dan Pantai Kutowinangun tahun 2014

\section{Analisis Dinamika Kedudukan Interface Tahun 1993 dan 2014}

Membandingkan hasil pendugaan geolistrik pada tahun 1993 dan 2014 terdapat perbedaan yang cukup ekstrim. Tahun 1993, semua jalur pendugaan terdeteksi adanya Interface dengan kedalaman yang bervariasi, sementara hasil pendugaan tahun 2014 sama sekali tidak mendeteksi adanya Interface. Secara teoritis, kedalaman Interface memang bersifat dinamis. Hal ini sejalan dengan pendapat Young Kim et al. (2009) dan Rotzoll et al. (2010), bahwa kedudukan Interface tidak bersifat statis, namun sangat dinamis tergantung dari faktorfaktor yang mempengaruhinya, seperti pengambilan airtanah, sifat-hidrolika air dan perbedaan musim.

Saat tekanan airtanah tawar dari daratan sangat kuat, Interface akan semakin menjauh dari daratan atau semakin dalam, sedangkan apabila tekanan dari airtanah tawar di daratan kurang begitu kuat, Interface dapat semakin menjorok ke daratan atau makin dangkal. Selain itu, kedudukan Interface juga sering dipengaruhi oleh perbedaan musim yaitu musim penghujan dan musim kemarau. Memperhatikan musim dilakukannya penelitian, pada tahun 1993 yang mendeteksi adanya Interface, justru pendugaan geolistrik dilakukan pada musim penghujan (Januari 1993) yang mestinya jumlah airtanah tawarnya juga lebih banyak, sedangkan pada penelitian tahun 2014 ini, pendugaan gelistrik dilakukan pada musim kemarau (Agustus 2014). Oleh karena itu, penyebab perbedaan musim dapat diabaikan.

Ditinjau dari pengambilan airtanah, Pesisir Kebumen relatif statis baik ditinjau dari pertambahan penduduk maupun kegiatan industri, sehingga variasi pengambilan airtanah akibat kedua aspek tersebut relatif kecil. Oleh sebab itu, pengaruh dari aspek pengambilan airtanah juga dapat diabaikan.

Hal paling masuk akal adalah adanya perubahan tataair berupa pertambahan akumulasi resapan air hujan secara kontinyu selama 21 tahun. Air hujan yang jatuh di daerah ini dapat meresap secara lebih intensif di daerah beting gisik. Akibatnya jumlah airtanah yang berada di daerah ini bertambah besar dengan daya desak yang kuat, sehingga mampu menekan air laut menjauhi daratan atau ke arah dalam. Selain itu daerah back swamp yang terdapat di wilayah ini juga tidak lagi kemasukan air laut pada saat pasang. Hasil pengamatan di lapangan maupun wawancara dengan penduduk menunjukkan tidak adanya sumur penduduk yang berasa asin.

\section{KESIMPULAN}

Berdasarkan hasil kajian yang telah dilakukan, maka dapat disimpulkan, hasil pendugaan geolistrik pada tahun 2014, menunjukkan bahwa muka freatik airtanah tawar ditemukan pada kedalaman antara 2 hingga 10 meter dari permukaan tanah. Hasil pendugaan tidak mendeteksi adanya Interface di semua jalur pengukuran, karena tidak ditemukannya lapisan dengan nilai tahanan jenis kurang dari $1 \Omega \mathrm{m}$; dan Pendugaan geolistrik pada tahun 1993 dan 2014 menunjukkan hasil yang berbeda. Hasil pendugaan Geolistrik pada tahun 1993 menunjukkan bahwa semua jalur pendugaan terdeteksi adanya Interface, sedangkan pada tahun 2014 tidak mendeteksi adanya Interface. Hal ini disebabkan oleh desakan airtanah tawar yang semakin kuat karena jumlahnya yang semakin besar akibat akumulasi peresapan air hujan ke dalam airtanah yang intensif dan terjadi pembilasan air laut oleh air tawar yang intensif. Selain itu, daerah back swamp yang terdapat di wilayah ini tidak lagi kemasukan air laut pada saat pasang.

\section{UCAPAN TERIMA KASIH}

Tulisan ini merupakan bagian dari penelitian yang berjudul "Dinamika Kedudukan Interface di Pesisir Kebumen" yang dibiayai dari Dana Penerimaan Negara Bukan Pajak, Fakultas Geografi, Universitas Gadjah Mada Tahun Anggaran 2014. Ucapan terima kasih disampaikan kepada segenap Pimpinan Fakultas Geografi UGM atas kesempatan dan biaya yang diberikan. 


\section{DAFTAR PUSTAKA}

Basack. S., Bhattacharya, A.K., Sahana, C \& Maity, P. (2010). A Study on Saline Water Intrusion and Fresh Water Recharge Relevant to Coastal Environment. Wheas Transactions on Fluid Mechanics, Issue 3, Vol. 5, July 2010.

Fetter, C.W. (2001). Applied Hydrogeology. PrenticeHall, Inc, Upper Saddle River New Jersey.

Goldenberg, L.C., Magaritz, M \& Mandel, S. (1983). Experimental Investigation on Irreversible Changes of Hydraulic Conductivity on the Seawater-Freshwater Interface in Coastal Aquifers. Water Resources Research 19 (1) : 225-242.

Marfai, M.A. \& King, L. (2008). Tidal Inundation Mapping under Enhanced Land Subsidence in Semarang, Central Java, Indonesia. Natural Hazards, 44(1), 93 - 109.

Marfai, M.A., Mardiatno, D., Cahyadi, A., Nucifera, F. \& Prihatno, H. (2013). Pemodelan Spasial Banjir Rob Berdasarkan Skenario Perubahan Iklim dan Dampaknya di Pesisir Pekalongan. Bumi Lestari, 13(2), $244-256$.

Purnama, S. (2002). Hasil Aman Eksploitasi Airtanah di Kota Semarang Propinsi Jawa Tengah. Majalah Geografi Indonesia, 16(2), 77 - 85.

Purnama, S. \& Sulaswono, B. (2006). Pemanfaatan Teknik Geolistrik untuk Mendeteksi Persebaran Airtanah Asin pada Akuifer Bebas di Kota Surabaya. Majalah Geografi Indonesia, 20(1), 5266

Purnama, S., Febriarta., Cahyadi, A., Khakhim, N., Ismangil, L. \& Prihatno, H. (2013a). Analisis Karakteristik Akuifer Berdasarkan Pendugaan Geolistrik di Pesisir Kabupaten Cilacap Jawa Tengah. Jurnal Geografi, 11(22), 155 - 165.

Purnama, S., Cahyadi, A., Febriarta., Khakhim, N., \& Prihatno, H. (2013b). Identifikasi Airtanah Asin Berdasarkan Pendugaan Geolistrik di Pesisir Kota Cilacap Jawa Tengah. Geomedia, 11(2), 183 190.

Purnama, S., Marfai, M.A., Anggraini, D.F., \& Cahyadi, A. (2015). Estimasi Risiko Kerugian Ekonomi Akibat Banjir Rob Menggunakan Sistem Informasi Geografis di Kecamatan Penjaringan, Jakarta Utara. Jurnal Spatial, 14(2), 8 - 13.

Rotzoll, K., Oki, D.S., \& El-Kadi, A.I., (2010). Changes Of Freshwater-Lens Thickness In Basaltic Island Aquifers Overlain By Thick Coastal Sediments. Hydrogeol. J. 18, 1425-1436.

Rushton, K.R. (2003). Groundwater Hydrology : Conceptual and Computational Models. John Wiley \& Sons Ltd, The Atrium, Southern Gate, Chichester, West Sussex
Saha, D.K and Choudhury, K. (2005). Saline Water Contamination of The Aquifer Zones of Eastern Kolkata. J. Ind. Geophys. Union 9 (4) : 241-247.

Setiadi, H. (2003). Peta Cekungan Airtanah Provinsi Jawa Tengah dan Daerah Istimewa Yogyakarta. Direktorat Tata Lingkungan Geologi dan Kawasan Pertambangan, Bandung.

Simoen, S., Suyono \& Purnama, S. (1993). Penyebaran Penyusupan Air Laut ke dalam Airtanah di Daerah Pantai Selatan Jawa Tengah dan Daerah Istimewa Yogyakarta. Lembaga Penelitian UGM, Yogyakarta.

Todd, D.K. \& Mays, L.W.. (2005). Groundwater Hydrology. John Wiley \& Sons, New York.

Young Kim, K., Suk Park, Y. \& Pyo Kim, G., (2009). Dynamic Freshwater-Saline Water Interaction In The Coastal Zone Of Jeju Island, South Korea. Hydrogeol. J.17, 617-629.

Zohdy, A.A.R, Eaton, G.P \& Mabey, D.R. (1980). Application of Surface Geophysics to Groundwater Investigation. United States Department of The Interior, Washington. 